\title{
Correction to: Importance of baseline musculoskeletal ultrasound findings in the prognosis of rheumatoid arthritis
}

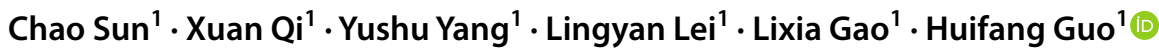

Published online: 28 January 2022

(c) International League of Associations for Rheumatology (ILAR) 2022

\section{Correction to: Clinical Rheumatology \\ https://doi.org/10.1007/s10067-021-06017-7}

The article "Importance of baseline musculoskeletal ultrasound findings in the prognosis of rheumatoid arthritis", written by Chao Sun, Xuan Qi, Yushu Yang, Lingyan Lei, Lixia Gao, Huifang Guo, was originally published online on the publisher's internet portal on 18 January 2022 with Open Access under a Creative Commons Attribution 4.0 International License, which permits use, sharing, adaptation, distribution and reproduction in any medium or format, as long as you give appropriate credit to the original author(s) and the source, provide a link to the Creative Commons licence, and indicate if changes were made. The images or other third party materials in this article are included in the article's Creative Commons licence, unless indicated otherwise in a credit line to the material. If material is not included in the article's Creative Commons licence and your intended use is not permitted by statutory regulation or exceeds the permitted use, you will need to obtain permission directly from the copyright holder. To view a copy of this licence, visit http:// creativecommons.org/licenses/by/4.0.

With the author's/authors' decision to cancel Open Access the copyright of the article changed on 26 January 2022 to (C) International League of Associations for Rheumatology (ILAR) 2022 with all rights reserved.

Publisher's Note Springer Nature remains neutral with regard to jurisdictional claims in published maps and institutional affiliations.

The original article can be found online at https://doi.org/10.1007/ s10067-021-06017-7.

Huifang Guo

guohfch@126.com

1 Department of Rheumatology and Immunology, the

Second Hospital of Hebei Medical University, No. 215,

Heping West Road, Xinhua District, Shijiazhuang 050000,

Hebei Province, China 